\title{
The use of the fluidized bed boiler for the disposal of the multi-material packaging waste
}

\author{
${ }^{1}$ Jadwiga Zabagło, ${ }^{1}$ Jerzy Baron, ${ }^{2}$ Małgorzata Olek, ${ }^{2}$ Stanisław Kandefer, ${ }^{1}$ Witold Żukowski \\ Cracow University of Technology, ul. Warszawska 24, 31-155 Cracow, Poland, e-mail: zabaglo@chemia.pk.edu.pl \\ ${ }^{1}$ Department of Inorganic Chemistry and Technology, \\ ${ }^{2}$ Department of Heat Engineering and Air Protection
}

\begin{abstract}
The paper presents the results of the disposal of packaging waste from two companies: Tetra Pak and Combibloc, carried out in a fluidized bed boiler of rated thermal power $0.5 \mathrm{MW}$. The material introduced into the fluidized bed boiler underwent thermal and mechanical degradation in a sand bed of the temperature between 750 and $850^{\circ} \mathrm{C}$. The process proceeds auto-thermally, without the need of additional fuel. The appropriately chosen fluidization parameters caused the separation of the solid products of combustion from the deposit material. Presence of aluminum, part of it in an un-oxidized form, was confirmed in separated dust. The gaseous products of combustion contained the traces of oxides of nitrogen and sulfur, mainly originating from the remnants of food products contained in the packaging. However, the concentration of these oxides met the requirements of emission standards.
\end{abstract}

Keywords: packaging waste, thermal disposal, fluidization, heat recovery and aluminum recovery.

\section{INTRODUCTION}

Increase in a society's standard of living is inextricably linked with an elevated and increasingly easier access to consumer goods, including food. The expected standards in this area include, among others, access to fresh drinks, including milk products, in the quantities suited to the needs of individual customers. The appearance in the 1930s of the milk packed in cardboard boxes, in the U.S. was a response to these expectations and the requirements of an easy and cheap form of transportation of such products. Years of research in these packages have led to the assumption of the standard multi-layer packaging, universally identified, in the public awareness, with the products of Tetra Pak or Combibloc.

Each of the layers of the packaging has its own function, and the whole unit constitutes a safe, cheap and easy to use package. The cardboard layer representing approximately $75 \%$ of its mass provides resistance to mechanical damage and stability of shape, which is an essential factor during transport. The layer of polyethylene or polypropylene (approx. 20\% by weight of the packaging) constitutes a barrier to moisture and fat. The aluminum foil (about 5\% by weight of the packaging) effectively protects the contents from penetration by air, foreign odors, light and microorganisms $\mathbf{1}^{\mathbf{1}}$. This type of packages represents the exclusively non-reusable packaging. They are produced in a way which makes them impossible to recycle. Although such solutions exist, recycling of the material is technologically difficult, energy-intensive and too costly $^{2-4}$. Due to packages' high calorific value - over 20 $\mathrm{MJ} / \mathrm{kg}$, it would seem economically and ecologically justified to employ energy recycling ${ }^{5}$. Under current Sustainable Development Strategy ${ }^{6}$ the raw materials that have been used once for production should be recovered. This would reduce the stream of waste disposed of by depositing in landfills.

In the case of the multi-material packaging one option would be to stipulate to recovery of all the raw materials, but such technology might prove to be an uneconomic solution. In the process that we have analyzed the card- board and plastics have the chemical energy that can be recovered, in the form of heat, in the combustion process. Aluminum is recovered as a raw material. An effort is made so that at least some part of it was in an un-oxidized form.

\section{EXPERIMENTAL PART AND RESULTS}

The paper presents the results of the thermal disposal of the Tetra Pak and Combibloc packaging waste in a fluidized bed reactor equipped with the dust removal system, of the rated power $0.5 \mathrm{MW}$. A diagram of the water boiler with the perforated plate measuring $0.25 \mathrm{~m}^{2}$ has been presented in Figure 1. As the fluidized bed, building sand with fraction diameter less than $1.5 \mathrm{~mm}$ and weighing about $30 \mathrm{~kg}$ was used. Sawdust, wood pellets and hard coal were used to ignite the boiler. Upon attaining the bed temperature of about $800^{\circ} \mathrm{C}$, the multilayer packaging fed in at a rate of about $1 \mathrm{~kg} / \mathrm{min}$ was the sole fuel.

Some $32 \mathrm{~kg}$ of waste material was used in the course of combustion. As a result of combustion, 8.3 kilograms of dust were recovered from the settling chamber and $1 \mathrm{~kg}$ from the cyclones. ECOM SG Plus and Horiba PG-250 analyzers were employed for an up-to-date analysis of the chemical composition of exhaust gases $\left(\mathrm{O}_{2}, \mathrm{CO}_{2}, \mathrm{CO}\right.$, $\mathrm{SO}_{2}, \mathrm{NO}_{\mathrm{x}}$ ). The measurement of the volatile organic compounds was carried out using the JUM Model 3-200 analyzer. The results of the measurements of the concentrations of exhaust components were standardized by calculating the composition in such a way that in standard conditions the concentration of oxygen in the exhaust gases was $6 \%$. The dust concentration was obtained using the automatic dust meter EMIOTEST 2598 with moisture measurement. This most modern model of automatic dust meter meets the requirements included in the PN-Z-04030-7 $7^{7}$ standard concerning the measurements of dust concentration using the gravity method. The above mentioned standard was also used to calculate dust concentration and the emission into the atmosphere.

The combustion process proceeded in the temperature range $750-850{ }^{\circ} \mathrm{C}$, with low air excess in the bed, but 


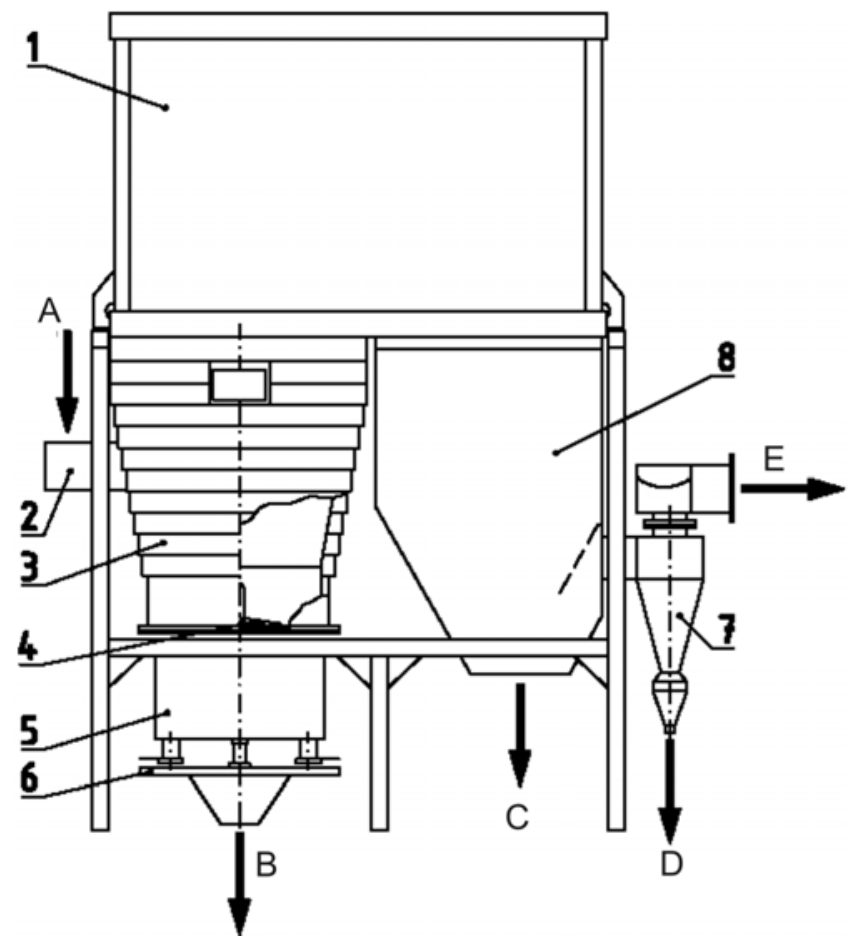

Figure 1. A diagram of KFD-s40 fluidized bed boiler: 1 - water jacket and water heat exchanger, 2 - fuel distributors, 3 - furnace chamber, 4 - perforated bottom, 5 - chamber below perforated bottom, 6 - ash remover, 7 - cyclones, 8 - settling chamber with heat exchanger, A - raw material, B, C, D - solid combustion products from: ash remover, settling chamber and cyclones respecively, E - draining off of exhaust gases

with a large stream of secondary air. Oxygen content in flue gases varied in the range $12-18 \%$ by volume and the concentration of CO $1200-2400 \mathrm{mg} / \mathrm{m}^{3}$ (Fig. 2 and 3). During the process, observed significant drop in oxygen concentration in the exhaust gases and rise in $\mathrm{CO}$ content was the result of a momentary increase in the amount of the fed multi-material packaging. There are also registered the changes in the concentration of volatile organic compounds, analogous to the changes in the concentration of CO. These are outlined in Figure 3, expressed as total organic carbon (TOC).

The content of $\mathrm{NO}_{\mathrm{x}}$ in the exhaust gases (Fig. 4) is (133 \pm 37$) \mathrm{mgNO}_{2} / \mathrm{m}^{3}$ and does not exceed the limit value $^{8}$ and, to an inconsiderable degree, depends on the changes of the stream of the fed material. In addition, the

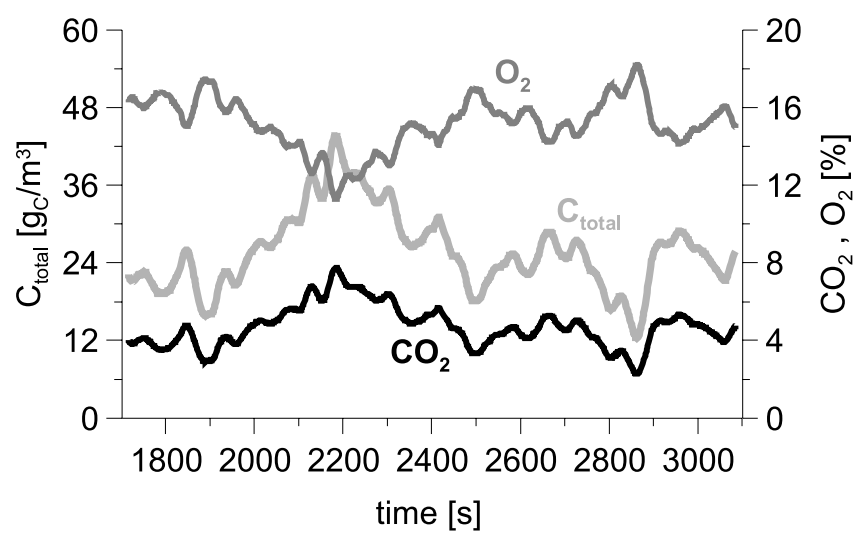

Figure 2. The contents of $\mathrm{O}_{2}, \mathrm{CO}_{2}$ and total carbon $\mathrm{C}_{\text {total }}$ in flue gases

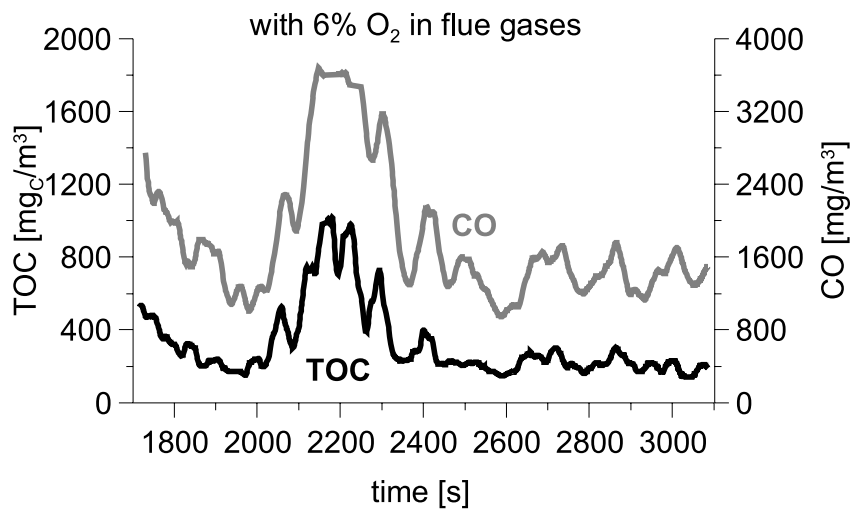

Figure 3. The standardized $\mathrm{CO}$ content and total organic carbon (TOC) in flue gases

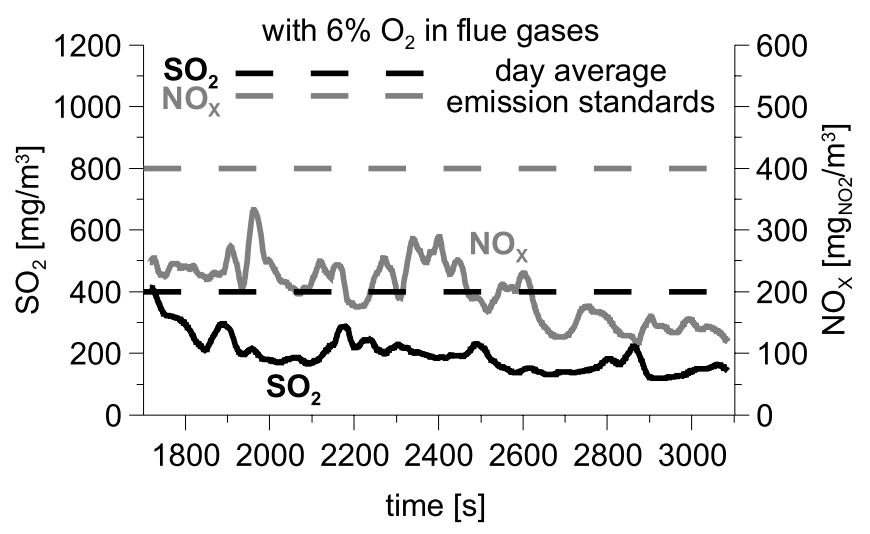

Figure 4. The standardized content of $\mathrm{SO}_{2}$ and $\mathrm{NO}_{\mathrm{x}}$ in the flue gases with emission standards set out in the Regulation of the Minister of Environment ${ }^{7}$

concentration of $\mathrm{SO}_{2}$ in the Flue gases is $(131 \pm 42) \mathrm{mg} /$ $\mathrm{m}^{3}$ and this level is lower than the limit $^{8}$ (Fig. 4). In the absence of significant amounts of nitrogen and sulfur in materials constituting the multi-material packaging, the concentrations of $\mathrm{NO}_{\mathrm{x}}$ and $\mathrm{SO}_{2}$ obtained are, to a larger extent, the result of the combustion of the remnants of the liquids contained in the packaging.

The material obtained from the settling chamber and cyclones (C and D in Figure 1) was subjected to granulometric analysis (test sieving was used), the results are shown in Figure 5. The material introduced to the bed underwent thermal and mechanical degradation, thus the reason for the distribution of particle sizes that deviate from the normal. Approximately $90 \%$ of the dust mass contains fractions of the diameter less than $0.43 \mathrm{~mm}$. The larger grains consisted mainly of firing up the boiler sawdust blown away during the ignition of the boiler as well as aluminum flakes that did not undergo greater fragmentation in the bed during the combustion. The whole dust also contains the crushed sand from the bed. The average ratio of $\mathrm{SiO}_{2}$ by weight of the total contents of cyclones residues exceeded $36 \%$, and exceeded $63 \%$ of total contents of settling chamber. Masses of aluminum in these materials were $11.0 \%$ and $61.6 \%$ ( $72.6 \%$ as sum) of $\mathrm{Al}$ included in the fuel combusted during test.

Dust concentration measurement after cyclones persisted for $28 \mathrm{~min}$ and was launched several minutes after the continuous dosage of the tested material was initiated. The physical parameters of the flue gases at the measuring cross-section and in the dust meter's sample gas train were collected in Table 1 . The dust concentration under nor- 


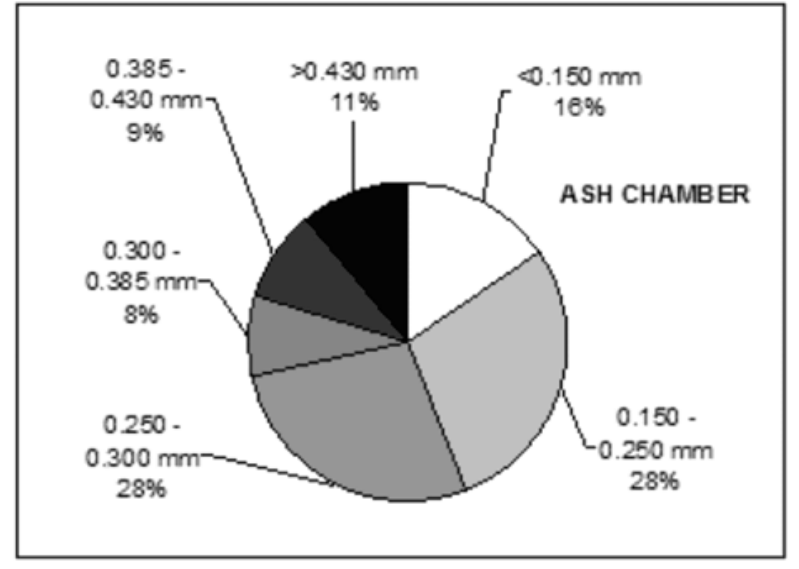

a)

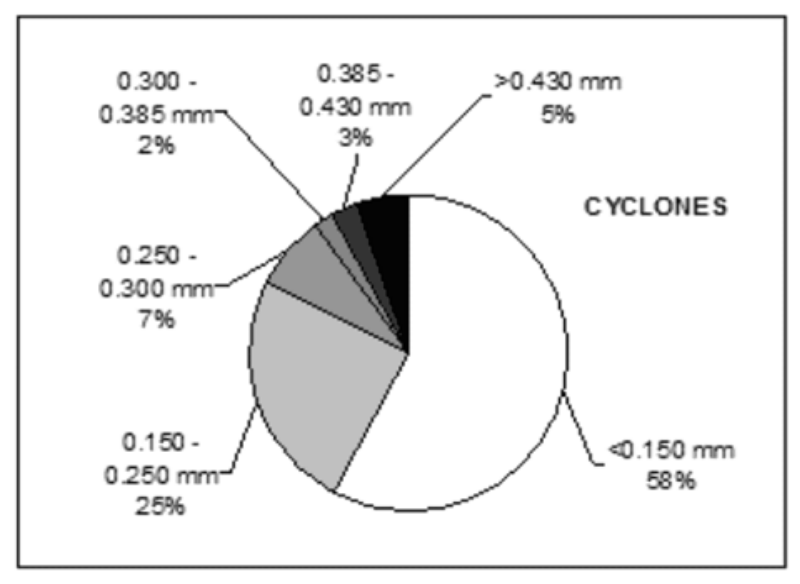

b)

Figure 5. The results of the granulometric analysis (test sieving) of the solid products of combustion: a) dust from the settling chamber, b) dust from the cyclone

malized conditions (pressure $1013 \mathrm{hPa}$, temperature 273 $\mathrm{K}$, dry gas) was $2.23 \mathrm{~g} / \mathrm{m}^{3}$, and the flue gases flow (the same conditions) was $1524 \mathrm{~m}^{3} / \mathrm{h}$. The dust mass flow was $3.4 \mathrm{~kg} / \mathrm{h}$. With the assumption that $\mathrm{Al}$ content in the dust after cyclones is the same as in the finest grade $(0.00-$ $0.15 \mathrm{~mm}$ ) of the dust collected, the amount of this element emitted was estimated as $19.7 \%$ of $\mathrm{Al}$ transferred to the boiler. It means that not only dust chamber and cyclones but also bag filters are necessary to rise the amount of $\mathrm{Al}$ collection efficiency from about $70 \%$ to higher than $90 \%$.

\section{CONCLUSIONS}

The conducted research studies point to the possibility of using the multi-material packaging waste as alternative fuel for heat production with a simultaneous recovery of aluminum. Such combination of two recovery processes allows for waste disposal with a simultaneous reduction in the waste stream discharged to the landfills, and thus its safe neutralization. Conducting the process of thermal processing in the fluidized bed boiler facilitated compliance with emission standards without an employment of any additional methods for the removal of $\mathrm{NO}_{\mathrm{x}}$ and $\mathrm{SO}_{2}$ from exhaust gases. This makes it possible to limit the costs associated with the use of additional resources and facilities for air protection. On the other hand, useful products are obtained in the form of heat energy and part of the recovered aluminum, what is more, the remaining solid products are compensated and environmentally safe - dust and ash that might also be of further use, for example, as ballast for mines or construction of road embankments.

Scientific work financed from school resources in the years 2008 - 11 as research project no. N N205 016134.

\section{LITERATURE CITED}

1. Information materials of Tetra Pak Company (2010). Retrieved February 1, 2010, from http://www.tetrapak.pl/ subpage.php?1/3/5

2. Nieminen, J. et al. (2001). EP1119646. European Patent Office.

3. Nieminen, J. et al. (2001). EP1119645. European Patent Office.

4. Nieminen, M., Kurkela, E. (2000). EP0972088. European Patent Office.

5. Żukowski, W., Baron, J., Zabagło, J., Kandefer, S. \& Olek, M. (2008). Recovery of aluminum from multi-component packaging using a fluidized bed reactor. Pol. J. Chem. Tech. 10(4), 40 - 44. DOI: 10.2478/v10026-008-0046-y.

6. Brundtland, G.H. (1987). Our Common Future. World Commission on Environment and Development: Oxford University Press. Retrieved February 1, 2010, from http:// www.un-documents.net/ocf-02.htm\#I.

7. Polish Committee of Standardization. (1994). Polish standard: Air purity protection - Tests for dust content Measurement of concentration and mass flow rate of particulate matter in waste gases by gravimetric method. PNZ-04030-7:1994. Warsaw. (in Polish: Ochrona czystości powietrza - Badania zawartości pyłu - Pomiar stężenia i strumienia masy pyłu w gazach odlotowych metodą grawimetryczną).

8. Ordinance of the Minister of Environment of December 20, 2005 on emission standards from installations, Official Journal of Laws of 2005, No. 260, item 2181 (in Polish: Rozporządzenie Ministra Środowiska z dnia 20 grudnia 2005r. w sprawie standardów emisyjnych z instalacji, Dz.U. 2005 nr 260, poz. 2181).

Table 1. The physical parameters of the flue gases at the measuring cross-section and in the dust meter's sample gas train

\begin{tabular}{|l|c|c|c|}
\hline Parameter & Unit & $\begin{array}{c}\text { Value at the measuring cross- } \\
\text { section }\end{array}$ & $\begin{array}{c}\text { Value in the dust meter's } \\
\text { sample gas train }\end{array}$ \\
\hline Temperature & ${ }^{\circ} \mathrm{C}$ & 150 & 18 \\
\hline Atmospheric pressure & $\mathrm{kPa}$ & 99.3 & 99.3 \\
\hline Static pressure & $\mathrm{kPa}$ & -0.1 & -26.1 \\
\hline Dynamic pressure & $\mathrm{Pa}$ & 74 & 77 \\
\hline Moisture content (dry gas basis) & $\mathrm{kg} / \mathrm{kg}$ & 0.080 & 0.003 \\
\hline Wet gas density & $\mathrm{kg} / \mathrm{m}^{3}$ & 0.798 & 0.895 \\
\hline Wet gas density (normalized conditions) & $\mathrm{kg} / \mathrm{m}^{3}$ & 1.262 & 1.320 \\
\hline Dry gas density (normalized conditions) & $\mathrm{kg} / \mathrm{m}^{3}$ & 1.322 & 1.322 \\
\hline
\end{tabular}

